\title{
Biodiversity of bulbous and tuberous geophytes from the EI Kala National Park (North-Eastern Algeria): checklist, vulnerability and conservation
}

Besma Dechir ${ }^{1}$, Atef Chouikh², Tarek Hamel ${ }^{3}$, Nawel Nadia Azizi ${ }^{4}$, Nawel Ganaoui ${ }^{1}$, AbdSlem Grira ${ }^{5}$, Ahmed Abdiouene $^{6}$, Mohamed Cherif Maazi ${ }^{1,7} \&$ Azzedine Chefrour ${ }^{1,8}$

1 Department of Biology, Fac. Sciences of Nature and Life, Mohamed-Cherif Messaadia University-Souk Ahras, 41000, Algeria.

2 Biology Department, Faculty of Natural Science and Life, El Oued University, Algeria.

3 Department of Biology, Faculty of Science, Badji Mokhtar University, Annaba-Algeria.

4 Department of Biology, Faculty of Science, Chadli Bendjedid University, El Tarf, Algeria.

5 El Kala National Park, El Tarf-Algeria.

6 National Institute of Forest Research of Souarekh, El Tarf, Algeria.

7 Laboratory of Aquatic and Terrestrial Ecosystems, Mohamed Cherif Messaadia University, Souk Ahras, 41000, Algeria.

8 Lab. Development and Control of Hospital Pharmaceutical Preparations, Department of Pharmacy, Faculty of Medicine, Badji Mokhtar University, Annaba, 23000, Algeria.

Correspondence

A. Chouikh

E-mail: atef-chouikh@univ-eloued.dz

Received: 18 November 2018

Accepted: 13 March 2019

Published on-line: 8 May 2019

\section{Resumen}

Biodiversidad de geófitos bulbosos y tuberosos del parque nacional El Kala (noreste de Argelia): lista de especies, vulnerabilidad y conservación

Treinta estaciones en el Parque Nacional El Kala (Noreste de Argelia) fueron objeto de un inventario florístico que se centró en el estudio de la ecología de geófitos bulbosos y tuberosos. La flora se caracteriza por una alta proporción de taxones raros y/o endémicos, entre ellos, 6 especies son endemismos algero-tunecinos pertenecientes a la familia Orchidaceae. En este trabajo, se da a conocer la presencia de una nueva especie para la flora argelina, Ophrys fusca subsp. lupercalis. Los análisis multivariantes revelaron, ciertas variables ambientales que determinan la distribución de los geófitos. Los lugares de interés son particularmente sensibles a las amenazas, particularmente las de origen antrópico.

Palabras clave: Especies raras; Endemismo; Flora.

\begin{abstract}
Thirty stations at the El Kala National Park (North Eastern Algeria) were the subject of a floristic focused on the study of the ecology of bulbous and tuberous geophytes. The floristic analysis was used to draw up a checklist of 67 species belonging to 36 genera and 14 families, among of which 19 species a high proportion of rare and /or endemic taxa; among them six signed taxa are endemic to algerian-tunisian mainly represented by family of Orchidaceae. In this work, we recorded the presence of a new species for the Algerian flora which is Ophrys fusca subsp. lupercalis. Multivariate analyses revealed certain environmental variables determining the distribution of geophytes. The visited sites show an alarming vulnerability and subject to threats, particularly anthropogenic ones.
\end{abstract}

Key words: Rare species; Endemism; Flora. 


\section{Introduction}

The Mediterranean plant biodiversity is commonly known in the world, as one of the most three remarkable ecosystems, regarding species richness, and endemism (Myers et al. 2000). The geographic analysis of the high plant diversity (Barthlott et al. 1999) and the areas of high endemism rate (Verlaque et al. 1997) have shown an important complimentary tool for, classifying the whole Mediterranean basin as a "hot-spot" through the world (Médail \& Quézel 1997).

Although, the flora of the southern- Mediterranean basin remains unknown, in particular the Algerian-Tunisian coastal mountainous, historically named "Kabylies-Numidia-Kroumirie", a phytogeographical name basically used by Quézel \& Santa (1962-1963), and having a great floristic richness and a very high endemism rate (Véla \& Benhouhou 2007).

The coastal of Numidia, "K3" in term biogeographical divisions as proposed by Quézel \& Santa (1962) makes at the east a precise biogeographic unit and an Important Plants Areas (IPA) (Yahi \& Benhouhou 2010) around the El Kala National Park (Marre 1992). In an ecological view point, this region is considered as highly important, considering its geographical location, climate, and its lakes and forests (de Bélair 1990). The yearly rainfalls are moderated in the coast, however they become abundant with the altitude (614 $\mathrm{mm}$ from El Kala city, $1.213 \mathrm{~mm}$ to the top of El Ghora soil) (Seltzer 1946), the ideal conditions for the development of bulbous and tuberous geophytes, tuber and rhizome (Danin \& Orshan 1990). The perennial subterranean organs promote the plant survivals in periods of serious climatic conditions (Procheș et al. 2015). This form of life is more common in Monocots, including families of Orchidaceae, Asparagaceae, Amaryllidaceae and Liliaceae, as well as some Eudicots taxa (Vesely et al. 2012).

In Algeria, very recent limited data are available on the bulbous geophytes, meanwhile some other studies have been carried out on Orchidaceeae (de Bélair 2000, de Bélair \& Boussouak 2002, de Bélair et al. 2005, Hadji \& Rebbas 2013, Babali et al. 2013, Kreutz et al. 2013, 2014, Bougaham et al. 2015, Beghami et al. 2015; Hamel \& Meddad-Hamza 2016, Hamel et al. 2017, Madoui et al. 2017, Boukehili et al. 2018) and Asparagaceae (Véla et al. 2016, Boubetra et al. 2017).

On top of that, the knowledge of the bulbous plants in Algeria and their distribution is mainly based on historical observations (Maire 19591987, Quézel \& Santa 1962), and consequently several new species of Algeria (not found in the historic references) and some taxa "synonyms" established in the distinct species have been discovered in the last few years (Rebbas \& Véla 2008, 2013, de Bélair et al. 2013).

- Geophytes are a group of flora whose ecology is not very well known. To this end, this article aims:

- To establish the inventory of geophytes at the El Kala National Park (North Eastern Algeria) and proceed to their identification and classification in order to draw up a floristic Checklist.

- To study the environmental factors influencing the ecological distribution of inventoried species.

- To enrich our database of authoctonous plants in the region in order to understand the phenomena encountered in the southern shore of the Mediterranean.

- To draw attention to the importance of protecting the flora of the region with a view to preserving it by putting in place conservation measures in order to develop a flora that is very important for biodiversity and the dynamics of forest ecosystems.

\section{Materials and methods}

\section{Study region}

The present study was conducted at El Kala National Park (EKNP), with a total surface area of 78438 ha (Fig. 1). Stands as one of the best landscape diversities, its biological heritage was found as one of the most diversified western Mediterranean basin (Stevenson et al. 1988, Benyacoub \& Chabi 2000, Brahmia et al. 2002). This site is located in the extreme North-Eastern Algeria, and boarded to the north by the Mediterranean Sea, to the east by the Algerian-Tunisian borders, to the west by the city of El Tarf and vast marshes of Mekhada, and to the south by the mountain of Medjerda (Benyacoub \& Chabi 2000).

According to the Emberger climagram (1955), the El Kala region is located within the bioclimatic sub-humid level of hot winter, to the limit 


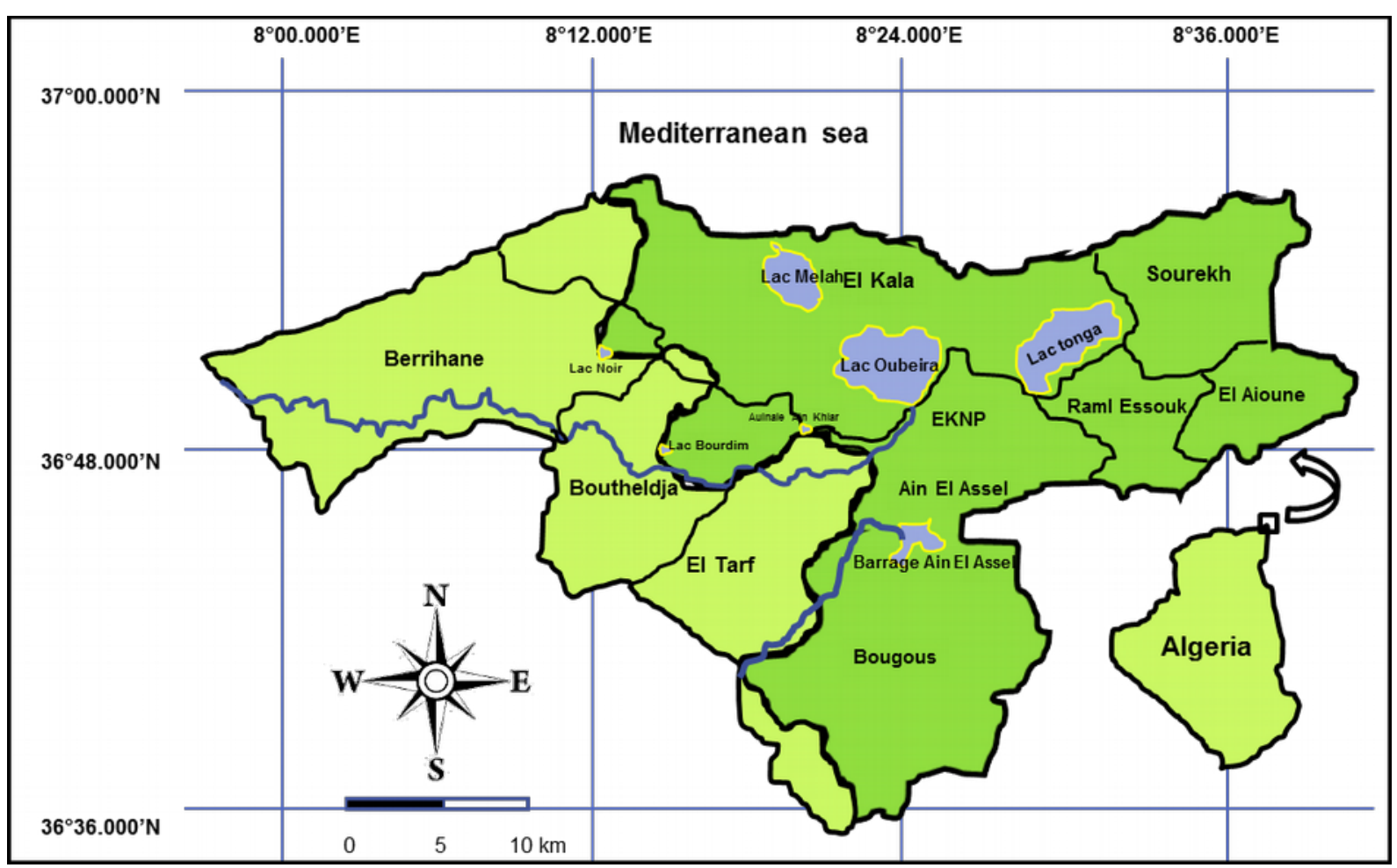

Figura 1. Ubicación del sitio de estudio EKNP.

Figure 1. Location of the study site EKNP.

of the humid level. The geological study showed that the study region mainly belongs to the Tertiary sector (Marre 1987), and it is represented by Numidian clays and sandstones, as well as deposits of sands, conglomerates, and banks of red or grey Pontian clay (Marre 1992).

\section{Sampling of plants}

\section{Floristic Study}

This study was carried out on 30 sites for the phytoecological monitoring, in which vegetation was studied for four years (2015-2018) with two seasons (Spring and Autumn) per year. The taxa have been identified accordingly to the new flora of Algeria and southern desert regions (Quézel and Santa 1962-1963), Flora of North Africa (Maire 1952-1987) and Italian Flora (Pignatti 1982).

The new nomenclature of the inventoried species were updated, taking into account recent works collected in the synonymic index, the bibliography of the North-Africa flora (Dobignard \& Chatelain 2010, 2013), and the Electronic African plant database, accessible at [http://www.villege.ch/musinfo/bd/cjb/africa/recherche.php].

In addition, the listed species were documented and indicated following their biogeographical type, as described by Pignatti (1982), Blanca et al. (2009), Dobignard \& Chatelain
(2010-2013) and Euro+Med Plant Base (http:// ww2.bgbm.org/EuroPlusMed/).

\section{Numerical analysis of the floristic data}

All the floristic reports were subjected to two analyses: Canonical analysis of correspondences (CAC), and Linear Discriminant Analysis (LDA). The linkage between the flora data and the environmental variables was obtained by the CAC. The patch resulting in CAC leads to visualize the explanatory percentage of a variable on another (Ter Braak 1995). Moreover, the data of site table were subjected to the LDA (Legendre and Legendre 2012) to obtain a segregation of the main groups of the studied sites. Both of these analysis tests were performed using $\mathrm{R}$ software (Core Team 2013) for basic statistical analysis (package ade4, version 3.0.2) (Dray et al. 2018).

\section{Results}

\section{Floristic composition}

The floristic sampling allowed us to list 67 species belonging to 36 genera and 14 botanical families. The distribution of families by number of species is presented in (Table 1).

According to table 1, the family Orchidaceae dominates with 21 species (31.3\%), second are the 
Amaryllidaceae and Asparagaceae with respectively $28.35 \%$ and $18 \%$ of the total number of taxa recorded, followed by Iridaceae with 6 species as $9 \%$. Whereas, Araceae and Liliaceae were found with 3 species $(4.4 \%)$, and thus the Colchicaceae family presented by a rate of $3 \%$ with two species. The Apiaceae, Aristolochiaceae, Crassulaceae, Oxalidaceae, Primulaceae, Ranunculaceae and Xanthorrhoeaceae participate in it by a low rate of $1.5 \%$ with only one species for each family.

The majority of species found in the study area are greatly presented in two places, namely Oued Djenan (28 species) and Brabtia (17 species), while the site Point of Chacal is the poorest site, containing just two species. Some species are widely distributed through the observation site and within the same site; this is the case of Drimia numidica (Fig. 4e) found in 24 sites with a frequency higher than 50 individuals per site, meanwhile others exist only in one site, case Moraea sisyrinchium (Djebel El Korsi), with a very low frequency ( 5 individuals). According to the global list of determined species, the composition of the global biological spectre (Table 1) showed that bulbous geophytes along with their 38 taxa (56.7\%) were found to be predominant on the tuberous geophytes (29 taxa presenting $43.3 \%$ ).

\section{Phytogeographical diversity}

The determined species belong to several chorological groups (Table 1):

Mediterranean set: this group dominates with 49 species, presenting $73.13 \%$ of the classified flora, including 26 species for the Mediterranean link element (sensu stricto), 11 species for the CircumMediterranean link element, 9 species for the Steno-Mediterranean link element, 2 species for the Euro-Mediterranean link element and 1 species for the Atlantic Mediterranean link element. In this set, the richest families are those of the best ones represented in the studied flora. The families; Orchidaceae, Amaryllidaceae, Asparagaceae and Iridaceae, respectively show 17 taxa, 12 taxa, 7 taxa, and 5 taxa, since other families may present 2 or 1 taxa.

Eurosiberian set: This set represents $5.97 \%$ of the studied flora (4 taxa), and it is represented by two European taxa (Colchicum autumnale L. and Gladiolus dubius Guss.), and two Eurasian taxa (Neotinea maculata (Desf.) Stearn and Gagea villosa (Parl.) Parl.).
Allocthonous set: This set includes only one taxa of Oxalidaceae (Oxalis pes-caprae L.) family.

Endemic set: It is important set in the studied flora, and it includes 13 species $(28.35 \%)$. Noteworthy, the great number of species was recorded in five sites; each one contains 3 species (Bougous, Chemin des Oiseaux, Djebel El Korsi, Feid El Allag and Oubeira). The Mellah site is considered as a poor site. It contains just one species. It has been observed that the Asparagaceae family is the richest in endemic species (five out of twelve taxa), followed by the Orchidaceae with 3 species, Amaryllidaceae, Apiaceae, Aristolochiaceae, Araceae and Primulaceae with respectively one taxa.

The genus Hyacinthoides Heist. ex Fabr. is represented by two taxa; while the rest of the genera are monospecific.

\section{Rarity}

The studied flora counted 19 rare species. This important number would due to the habitat diversity, especially the cork oak forests Quercus suber L., which include several rare and/or endemic species, like Allium duriaeanum J. Gay and Romulea ligustica Parl. subsp. ligustica. The species do not usually have the same heritage value; meanwhile some of them are endemic and rare, such as Serapias stenopetala Maire \& T. Stephenson and Aristolochia navicularis E. Nardi. Additionally, all these species are in the IUCN Red List (2017) along with different status (CR for $S$. stenopetala, LC for A. navicularis) (Table 2). Rare species of the region could be found in other countries, like the species of the northern element (Neotinea maculata) and the Mediterranean element (Allium commutatum Guss., Ophrys iricolor Desf.). Nevertheless, three species of this flora are protected according to the Algerian legislation (Executive decree $\left.\mathrm{N}^{\circ} 12 / 03,2012\right)$ providing the list of protected non-cultivated plant species): Anacamptis papilionacea (L.) R. M.Bateman, Pridgeon \& M. W. Chase, Bunium crassifolium (Batt.) Batt., Cyclamen africanum Boiss. \& Reut.

\section{Canonical Analysis of Correspondences (CAC)}

This analysis joins the 67 plant species and environmental variables. The outline drawn by the first and second axes has an inertia rate of $68.70 \%$ (Fig. 2). It evidenced the distribution of the sites as a function to the variables of the environment 


\begin{tabular}{|c|c|c|c|}
\hline Code & Taxa & Family & Biogeographic type \\
\hline $\mathrm{x} 1$ & Acis autumnalis (L.) Sweet & Amaryllidaceae & Mediterranean \\
\hline $\mathbf{X} 2$ & Allium ampeloprasum L. & Amaryllidaceae & Mediterranean \\
\hline $\mathbf{X} 3$ & Allium chamaemoly L. subsp. chamaemoly & Amaryllidaceae & Mediterranean \\
\hline X4 & Allium commutatum Guss. & Amaryllidaceae & Steno-Mediterranean \\
\hline $\mathbf{X 5}$ & Allium duriaeanum J. Gay & Amaryllidaceae & Algerian-Tunisian endemic \\
\hline $\mathrm{X} 6$ & Allium longispathum Delaroche & Amaryllidaceae & Circum-Mediterranean \\
\hline $\mathbf{X 7}$ & Allium nigrum $\mathrm{L}$. & Amaryllidaceae & Mediterranean \\
\hline $\mathrm{X8}$ & Allium roseum $\mathrm{L}$. & Amaryllidaceae & Mediterranean \\
\hline X9 & Allium subvillosum Salzm. ex Schult. \& Schult. f. & Amaryllidaceae & Mediterranean \\
\hline $\mathbf{X} 10$ & Allium triquetrum $\mathrm{L}$. & Amaryllidaceae & Mediterranean \\
\hline $\mathbf{X} 15$ & Ambrosina bassii L. & Araceae & Tyrrhenian subendemic \\
\hline $\mathrm{X} 43$ & $\begin{array}{l}\text { Anacamptis coriophora subsp. fragrans (Pollini) R. M. Bateman, } \\
\text { Pridgeon \& M. W. Chase }\end{array}$ & Orchidaceae & Circum-Mediterranean \\
\hline X44 & $\begin{array}{l}\text { Anacamptis papilionacea (L.) R. M. Bateman, Pridgeon \& M. W. } \\
\text { Chase }\end{array}$ & Orchidaceae & Circum-Mediterranean \\
\hline $\mathrm{x} 66$ & Anemone palmata L. & Ranunculaceae & Mediterranean \\
\hline $\mathrm{X} 16$ & Arisarum vulgare O. Targ. Tozz. & Araceae & Circum-Mediterranean \\
\hline $\mathrm{X} 18$ & Aristolochia navicularis E. Nardi & Aristolochiaceae & Tyrrhenian subendemic \\
\hline $\mathbf{X} 17$ & Arum italicum Mill. & Araceae & Euro-Mediterranean \\
\hline $\mathrm{x} 67$ & Asphodelus ramosus $\mathrm{L}$. & Xanthorrhoeaceae & Steno-Mediterranean \\
\hline $\mathrm{X} 19$ & Barnardia numidica (Poir.) Speta & Asparagaceae & Algerian-Tunisian endemic, Boreal / Libya \\
\hline $\mathbf{X} 20$ & Bellevalia mauritanica Pomel & Asparagaceae & North African endemic \\
\hline $\mathrm{x} 14$ & Bunium crassifolium (Batt.) Batt. & Apiaceae & Algerian-Tunisian endemic \\
\hline $\mathbf{X} 31$ & Colchicum autumnale L. & Colchicaceae & European \\
\hline $\mathbf{X} 32$ & Colchicum cupanii Guss. & Colchicaceae & Steno-Mediterranean \\
\hline $\mathrm{x} 65$ & Cyclamen africanum Boiss. \& Reut. & Primulaceae & North-East African endemic \\
\hline $\mathbf{X} 21$ & Drimia fugax (Moris) Stearn & Asparagaceae & Mediterranean \\
\hline $\mathbf{X} 22$ & Drimia numidica (Jord. \& Fourr.) J. C. Manning \& Goldblatt & Asparagaceae & Algerian-Tunisian/Spain endemic \\
\hline $\mathbf{X} 40$ & Gagea granatellii (Parl.) Parl. & Liliaceae & Mediterranean \\
\hline $\mathrm{X} 41$ & Gagea villosa (M. Bieb.) Sweet & Liliaceae & Eurasian \\
\hline $\mathrm{X} 34$ & Gladiolus dubius Guss. & Iridaceae & European \\
\hline $\mathbf{X} 23$ & Hyacinthoides aristidis (Coss.) Rothm. & Asparagaceae & Algerian-Tunisian endemic \\
\hline $\mathrm{X} 24$ & Hyacinthoides lingulata (Poir.) Rothm. & Asparagaceae & Maghreb endemic \\
\hline $\mathrm{X} 36$ & Moraea sisyrinchium (L.) Ker Gawl. & Iridaceae & Steno-Mediterranean \\
\hline $\mathbf{X 2 5}$ & Muscari comosum (L.) Mill. & Asparagaceae & Mediterranean \\
\hline $\mathrm{X} 11$ & Narcissus elegans (Haw.) Spach & Amaryllidaceae & Mediterranean \\
\hline $\mathbf{X} 12$ & Narcissus tazetta L. & Amaryllidaceae & Mediterranean \\
\hline $\mathrm{X} 45$ & Neotinea maculata (Desf.) Stearn & Orchidaceae & Eurasian \\
\hline $\mathrm{X} 26$ & Oncostema peruviana (L.) Speta & Asparagaceae & Mediterranean \\
\hline X46 & Ophrys apifera Huds. & Orchidaceae & Circum-Mediterranean \\
\hline $\mathrm{X} 47$ & Ophrys bombyliflora Link & Orchidaceae & Mediterranean \\
\hline X48 & Ophrys fusca subsp. fusca & Orchidaceae & Steno-Mediterranean \\
\hline $\mathbf{x} 50$ & Ophrys fusca subsp. lupercalis (Devillers \& Devillers-Tersch.) Kreutz & Orchidaceae & Mediterranean \\
\hline X49 & Ophrys iricolor Desf. & Orchidaceae & Mediterranean \\
\hline $\mathrm{X} 51$ & Ophrys lutea Cav. & Orchidaceae & Steno-Mediterranean \\
\hline X52 & Ophrys numida J. Devillers-Terschuren et P. Devillers & Orchidaceae & Algerian-Tunisian endemic \\
\hline $\mathrm{X} 53$ & Ophrys picta Link & Orchidaceae & Mediterranean \\
\hline X54 & Ophrys speculum Link & Orchidaceae & Circum-Mediterranean \\
\hline X55 & $\begin{array}{l}\text { Ophrys tenthredinifera subsp. ficalhoana (J.A. Guim.) M.R. Lowe et D. } \\
\text { Tyteca }\end{array}$ & Orchidaceae & Mediterranean \\
\hline X56 & Ophrys tenthredinifera subsp. tenthredinifera Willd. & Orchidaceae & Mediterranean \\
\hline $\mathrm{X} 57$ & Orchis lactea Poir. & Orchidaceae & Steno-Mediterranean \\
\hline $\mathbf{X 2 7}$ & Ornithogalum arabicum L. & Asparagaceae & Mediterranean \\
\hline $\mathbf{X 2 8}$ & Ornithogalum narbonense L. & Asparagaceae & Circum-Mediterranean \\
\hline $\mathbf{X 2 9}$ & Ornithogalum umbellatum $\mathrm{L}$. & Asparagaceae & Circum-Mediterranean \\
\hline $\mathrm{x} 64$ & Oxalis pes-caprae L. & Oxalidaceae & introduced \\
\hline $\mathbf{x} 13$ & Pancratium maritimum L. & Amaryllidaceae & Steno-Mediterranean \\
\hline X58 & Platanthera bifolia (L.) Rich. & Orchidaceae & Algerian-Tunisian endemic \\
\hline $\mathbf{X 3 0}$ & Prospero autumnale (L.) Speta & Asparagaceae & Circum-Mediterranean \\
\hline $\mathbf{X} 37$ & Romulea bulbocodium (L.) Sebast. \& Mauri & Iridaceae & Mediterranean \\
\hline $\mathbf{X 3 8}$ & Romulea ligustica Parl. subsp. ligustica & Iridaceae & Mediterranean \\
\hline
\end{tabular}

Tabla 1 (Continúa). Lista de plantas bulbosas y tuberosas registradas en el área de estudio.

Table 1 (Continues). List of bulbous-tuberous plants recorded in the study area. 


\begin{tabular}{clll}
\hline Code & \multicolumn{1}{c}{ Taxa } & \multicolumn{1}{c}{ Family } & \multicolumn{1}{c}{ Biogeographic type } \\
\hline X39 & Romulea ramiflora Ten. & Iridaceae & Mediterranean \\
X59 & Serapias lingua L. & Orchidaceae & Circum-Mediterranean \\
X60 & Serapias parviflora Parl. & Orchidaceae & Mediterranean \\
X61 & Serapias stenopetala Maire \& T. Stephenson & Orchidaceae & Algerian-Tunisian endemic \\
X62 & Serapias strictiflora Welw. ex Veiga & Orchidaceae & Circum-Mediterranean \\
X63 & Spiranthes spiralis (L.) Chevall. & Orchidaceae & Euro-Mediterranean \\
\hline X42 & Tulipa sylvestris subsp. australis (Link) Pamp. & Liliaceae & Mediterranean \\
X33 & Umbilicus rupestris (Salisb.) Dandy & Crassulaceae & Atlantic Mediterranean \\
\hline X35 & Xiphion junceum (Poir.) Parl. & Iridaceae & Steno-Mediterranean \\
\hline
\end{tabular}

Tabla 1 (Continuada). Lista de plantas bulbosas y tuberosas registradas en el área de estudio.

Table 1 (Continued). List of bulbous-tuberous plants recorded in the study area.

\begin{tabular}{lccc}
\hline Taxa & Scarcity & JORA 2012 & UICN 2017 \\
\hline Allium commutatum & $\mathrm{HR}^{*}$ & - & - \\
Allium duriaeanum & $\mathrm{HR}^{*}$ & - & - \\
Ambrosina bassii & $\mathrm{C}$ & - & $\mathrm{LC}$ \\
Anacamptis papilionacea & $\mathrm{LR}$ & $\mathrm{P}$ & - \\
Aristolochia navicularis & $\mathrm{R}$ & - & $\mathrm{LC}$ \\
Barnardia numidica & $\mathrm{C}$ & - & - \\
Bellevalia mauritanica & $\mathrm{QC}$ & - & - \\
Bunium crassifolium & $\mathrm{HR}$ & $\mathrm{P}$ & - \\
Cyclamen africanum & $\mathrm{HC}$ & $\mathrm{P}$ & - \\
Drimia numidica & $\mathrm{C}$ & - & - \\
Hyacinthoides aristidis & $\mathrm{QC}$ & - & - \\
Hyacinthoides lingulata & $\mathrm{C}$ & - & - \\
Neotinea maculata & $\mathrm{R}$ & - & - \\
Ophrys iricolor & $\mathrm{R}^{*}$ & - & - \\
Ophrys numida & $\mathrm{R}^{*}$ & - & - \\
Platanthera bifolia & $\mathrm{R}$ & - & - \\
Romulea ligustica subsp. & $\mathrm{R}$ & - & - \\
ligustica & $\mathrm{R}^{*}$ & - & - \\
Serapias lingua & $\mathrm{HR}$ & - & $\mathrm{CR}$ \\
Serapias stenopetala & & &
\end{tabular}

Tabla 2. Taxones endémicos y raros observados en el área de estudio (LR: menos raro; R: raro; HR: muy raro; QC: bastante común; C: común; HC: muy común; LC: menor preocupación, CR: en peligro crítico; P: Protegido). Datos históricos (Quézel \& Santa 1962-1963) modificados*.

Table 2. Endemic and rare taxa observed in the study area (LR: less rare; R: rare; HR: highly rare; $\mathrm{QC}$ : quite common; $\mathrm{C}$ : common; HC: highly common; LC: minor concern, CR: in critical hazard; P: Protected). Nowadays, the historical data (Quézel \& Santa 1962-1963), including several taxa, have been modified*.

and the physiognomy of vegetation.

The two sites of marine fringes (R20 and R23) appear relatively isolated on the positive side of the axis 2 , and are characterized by their height position. The site R20 occupies a sandy substrate, and is distinguished by the species Pancratium maritimum L. (X13). Although, the site R23 is linked to the maritime cliff of the town of Vielle Calle and is distinguished by the species Allium subvillosum Salzm. ex Schult. \& Schult. f. (X9).

Sites (R1, R10, R5, R9, R28, R29, R7, R4, R8, $\mathrm{R} 3, \mathrm{R} 6$ and R13) are associated with five dominant factors of the negative part of the Axis 2: herbaceous cover rate (Trhe), tree cover lignified rate (Trli), slope and bulb overlap area. The altitude (Alti) also mediates for the Bougous site (331 MASL) and El Ghora (445 MASL), and so these two sites limit the distribution of two endemic species; Bellevalia mauritanica Pomel (X20) and Platanthera bifolia L.) Rich. (X58). These fourteen sites were found to include a great number of listed species.

The three sites R18, R21 and R2, containing Romulea bulbocodium (L.) Sebast. \& Mauri (X37), Colchicum cupanii Guss. (X32), Arum italicum Mill. (X17) and Serapias stenopetala (X61) were found isolated, in relation to the Numidian sandstone substrates.

The thirteen sites (R24, R14, R22, R25, R30, R26, R15, R12, R11, R17, R19, R27 and R16) were found grouped, in relation with the NorthEastern exposure. They include the species linked to overgrazing as Asphodelus ramosus L. (X67), Ophrys bombyliflora Link (X47) and Ophrys tenthredinifera subsp. tenthredinifera (J.A. Guim.) M.R. Lowe et D. Tyteca (X56).

\section{Typology of sites}

The Linear Discriminant Analysis performed on a total of 30 sites and 7 environmental variables has evidenced the existence of an altitude gradient in the direction of axis 1 (Fig. 3). The plan made through the first and the second axes summarize an inertia rate of $84.94 \%$.

The group «G5» includes the two sites (R20 and R23), characterized by a variable substrate, and located in the maritime beach of the studied region.

The group «G4» includes the six sites (R8, $\mathrm{R} 10, \mathrm{R} 11, \mathrm{R} 12, \mathrm{R} 18$ and R22), organized around a high rate of herbaceous associated with a weak representation of the lignified plants.

The group «G1» contains two sites (R1 and R27), and it solely includes lignified species on calcareous substrata.

The group «G2» stretch throughout the negative 


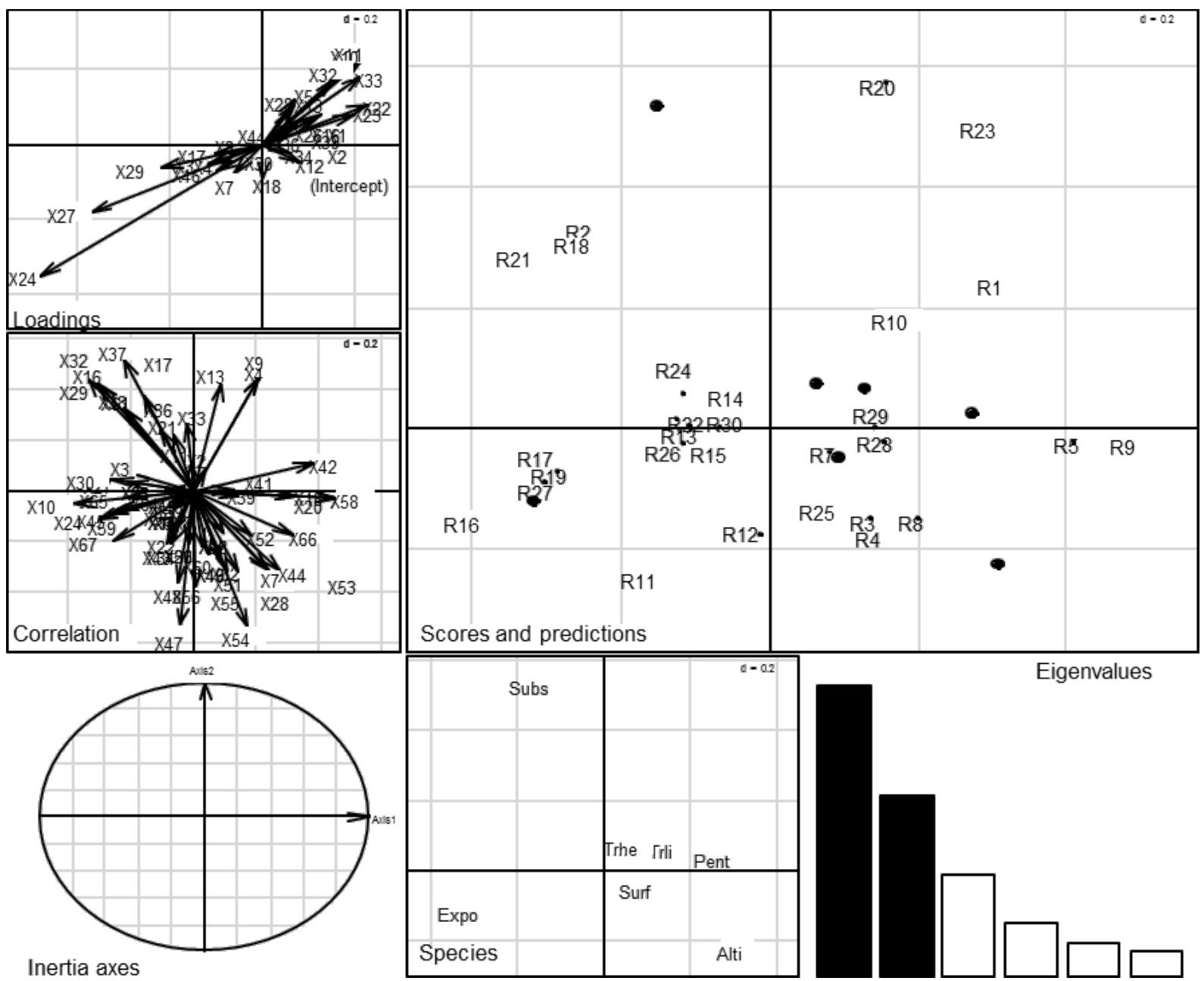

Figura 2. Mapa del análisis canónico de correspondencias (CAC); 30 sitios x 67 especies x 7 variables ambientales

Figure 2. Map of the canonical analysis of correspondences (CAC); 30 sites x 67 species x 7 environmental variables.

part of axis 2, and it is formed by two sites of medium and high altitude (R2, R3, R4, R5, R6, R13, R14, R15, R16, R17, R19, R21, R24, R25, $\mathrm{R} 26, \mathrm{R} 28, \mathrm{R} 29$ and R30). These sites are absolutely characterized by high rates of herbaceous and lignified, along with large areas of bulbous plants.

Lastly, the group «G3» is constituted by two sites R7 and R9, and it occupies a ridge at high altitude. These two sites are characterized by high rates of lignified, and mainly by strong slopes $(45 \%)$.

\section{Discussion}

\section{Floristic composition}

The inventory of bulbous and tuberous species at the El Kala National Park evidenced the presence of 67 taxa with specific or sub specific ranks. Three families (Orchidaceae, Amaryllidaceae and
Asparagaceae) are principally represented within the inventoried area, and they are highly dominant in the monocotyledon flora geophytes of the Mediterranean basin (Parsons \& Hopper 2003).

Moreover, the orchid flora of the studied area could be considered as quite interesting when compared with that obtained in region of Souk Ahras by Boukehili et al. (2018), who have estimated 27 species, and that reported by Hamel \& Meddad-Hamza (2016), showing 20 species in Edough peninsula site, as well as the previous results of Martin et al. (2015), regarding 50 species recorded in Tunisia.

This dominance of orchids in the determined flora would be strongly related to edaphic and climatic factors, as indicated by de Bélair et al. (2005), Kreutz et al. $(2013,2014)$ and Hamel et al. (2017).

The First-order diversity is high in the other remaining families; they do not only present large number of species, but also a high family numbers 


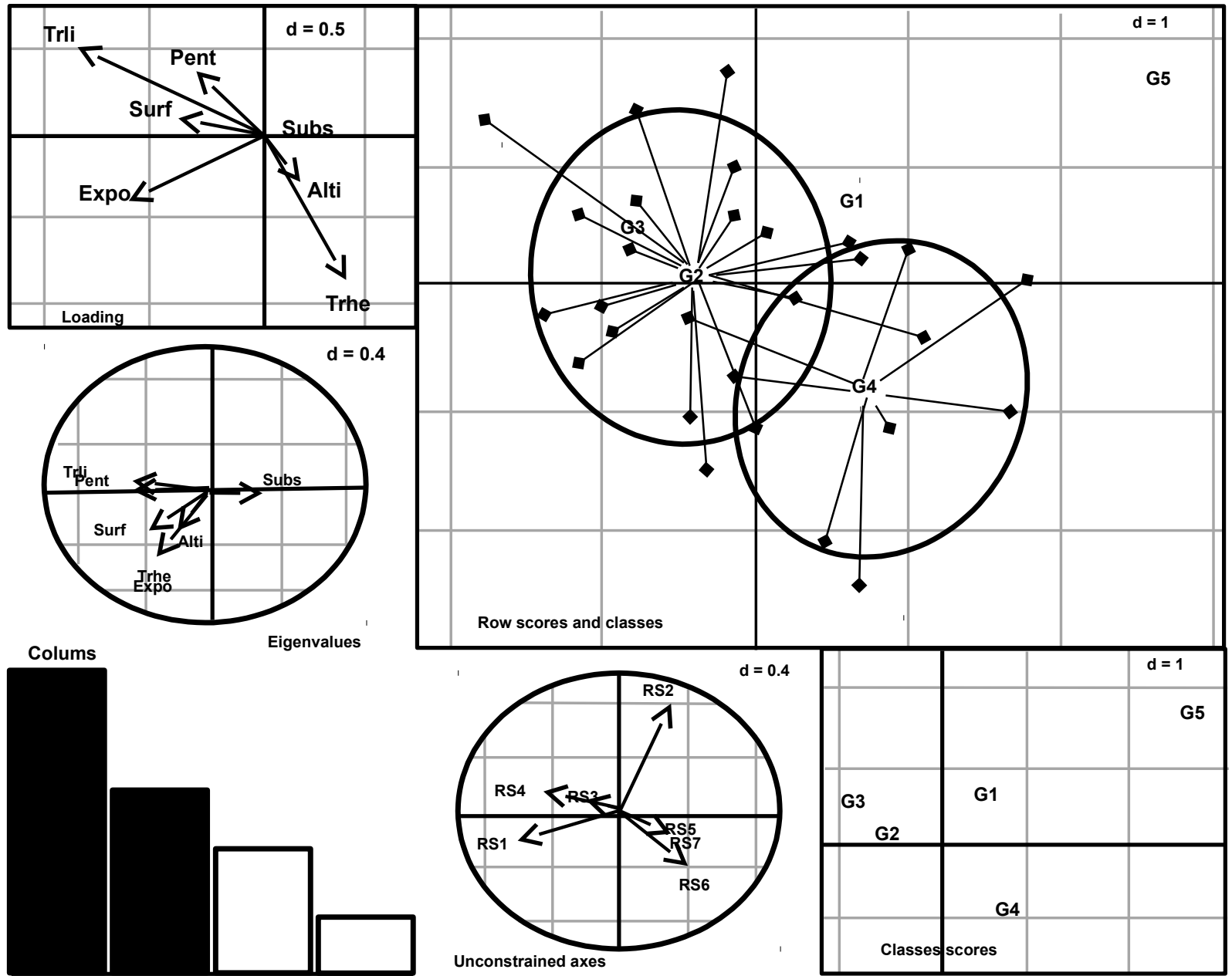

Figura 3. Mapa del análisis discriminante lineal (LDA) en 30 sitios x 7 variables ambientales.

Figure 3. Map of the Linear Discriminant Analysis (LDA) on 30 sites x 7 environmental variables.

(Daget \& Gaston 2001). These results are concord with those obtained by the work carried out on the vascular flora of the Edough Peninsula by Hamel (2013), and the work of de Bélair (1990) on the vegetation of the lacustrine zones of El Kala National Park.

In this study, we have noticed the presence of a new species belonged to Algerian flora Ophrys fusca subsp. lupercalis (Fig.4a). Though, the species was indicated as widely distributed in the Mediterranean basin (Devillers \& Devillers-Terschuren 1994), since the flora of Algeria (Quézel \& Santa 1962-1963) and that of the North-Africa (Maire 1952-1987) ignore its presence. This is alike to Tunisia flora (Le Floc'h et al. 2010). The recent literature works done on the North-Africa flora (Dobignard \& Chatelain 2010) indicate probably the presence of the species in Tunisia.

Hence, El-Kala is believed to be a biogeographical crosslink for its fauna and flora (de Bélair 2005).
Additionally, the unexpected discovering of this species, too far from its classical sites of the western Mediterranean (Spain) (Blanca et al. 2009), auguring the existence of other populations, leading to searching within potential area of the populations.

The studied flora showed a set of heterogeneous biogeographical value, whose establishment in fact responds to the extreme palaeogeographical and paleoclimatic complexities of the Mediterranean region (Quézel \& Médail 2003). Indeed, the Mediterranean element dominates with $73.13 \%$, and this is in line with those reported by Quézel (1983), showing an increase in the Mediterranean species in the flora of NorthAfrica. Our study area includes 13 endemic species of rate $28.35 \%$, as $17.1 \%$ of the regional endemic species of sector "K3" (Numidia) found in our study area. This percentage is higher than that given by Hamel et al. (2013) for the endemic geophytes of Edough Peninsula (3.8\%). 
Whilst, the Eurosiberian species exhibits a low percentage $(5.97 \%)$, and it overall represents the remnants of a flora found in North Africa during the glacial periods, and it appears almost exclusively from the Iberian Peninsula (Quézel 1978).

\section{Habitat diversity of the studied flora}

The cork oak forest and lawns of the study area was found as rich in species, containing more than 40 species for each (Table 3), while the maritime cliffs and Zenaie oak include, respectively 12 and 11 species (poorest site), and that eucalyptuses occupy the intermediate position with 14 species.

These results confirm that the Numidia region (where indicate our site) and other areas, such as Kabylie and Kroumirie in Tunisia, presenting a high floristic richness, are classified as new hotspots, along with the ten other regional hotspots of Mediterranean biodiversity (Médail \& Quézel 1997, Médail \& Diadema 2006, Véla \& Benhouhou 2007). As for endemism, it is the most common in the cork oak forests, with 9 taxa, followed along with Zenaie oak forests and lawns, respectively 5 and 3 species.

Eucalyptaie and sea cliffs are the poorest sites with 2 taxa for each, which explains that the floristic accompanying the cork oak forests possesses coping mechanisms throughout the summer dry season (nearly 4 months) that characterizes the Eastern Numidia (Bennadja et al. 2013).

In contrast, the distribution of the endemic species does not occur spontaneously. They were found in regions, whose flora has to do with the recent or previous geographical reasons (Boulos 1997, Verlaque et al. 1997). According to Barbéro et al. (2001), this richness of endemic herbaceous forests accounts for the variability of biogeo-

\begin{tabular}{|c|c|c|}
\hline Habitat & No. spp & Endemic taxa \\
\hline $\begin{array}{l}\text { Cork } \\
\text { forest }\end{array}$ & 56 & $\begin{array}{l}\text { Allium duriaeanum, Ambrosina bassii, } \\
\text { Aristolochia navicularis, Barnardia } \\
\text { numidica, Bellevalia mauritanica, Bunium } \\
\text { crassifolium, Cyclamen africanum, Drimia } \\
\text { numidica, Hyacinthoides lingulata }\end{array}$ \\
\hline Lawns & 41 & $\begin{array}{l}\text { Drimia numidica, Ophrys numida, Serapias } \\
\text { stenopetala }\end{array}$ \\
\hline Eucalyptaie & 14 & Drimia numidica, Hyacinthoides lingulata \\
\hline $\begin{array}{l}\text { Maritime } \\
\text { cliffs }\end{array}$ & 12 & Drimia numidica, Cyclamen africanum \\
\hline $\begin{array}{l}\text { Zenaie oak } \\
\text { forest }\end{array}$ & 11 & $\begin{array}{l}\text { Cyclamen africanum, Drimia numidica, } \\
\text { Hyacinthoides aristidis, Platanthera bifolia, } \\
\text { Hyacinthoides lingulata }\end{array}$ \\
\hline
\end{tabular}

Tabla 3. Riqueza florística de los hábitats muestreados en el área de estudio. (No. spp: Número de species)

Table 3. Floristic richness of the sampled habitats in the study area. (No. spp: Number of species) graphic,ecological states and the fragmentation of the continental areas in relation with anthropogenic actions.

\section{Heritage Value of the listed species}

The recorded flora was found to be very rich by endemic taxon (13 taxa), which are either endemic of the regional hotspots «Kabylies-Numidia-Kroumirie» (Véla \& Benhouhou 2007) or sub endemic of this sector with a supplementary separated area (Table 4):

Algerian-Tunisian endemics include six species: Allium duriaeanum, Bunium crassifolium, Hyacinthoides aristidis, Ophrys numida (Fig. 4h), Platanthera bifolia (Fig. 4g) and Serapias stenopetala (Fig. 4d). Véla \& Benhouhou (2007) and Hamel et al. (2013) argue that these endemic borders with Tunisia correspond less to areas of specialized hyperendemism than to large areas of biogeography where endemic species are locally rare or even abundant.

Algerian-Tunisian/Spain endemics include mainly one taxon (Drimia numidica) which is commonly known in north-eastern of Algeria with less important distribution areas (Quézel \& Santa 1962);

Maghreb endemics include three taxa: Cyclamen africanum (Fig. 4c), Hyacinthoides lingulata (Fig. 4b) and Bellevalia mauritanicae.

Algerian-Tunisian endemic, Boreal / Libya include only one taxa: Barnardia numidica.

Sub-endemics: include two taxa (Ambrosinia bassii and Aristolochia navicularis). The presence of endemic Tyrrhenian strain ( 2 taxa) could be explained by the terrestrial connections passed through the Algerian coast Tell with the Tyrrhenia (Quézel 1964, Hamel \& Boulemtafes 2017).

Compared to the work of Hamel et al. (2013), carried out on the rare and endemic flora of Edough Peninsula, the endemic numbers found in our region could be considered as important, and showed about $17.1 \%$ of endemic flora of sector "K3", including 76 taxa (Véla \& Benhouhou 2007). Nevertheless, two endemic plants are classified as typical species in the identification of Algerian ZIP (El Kala 1): Serapias stenopetala and Bunium crassifolium (Yahi et al. 2012).

The rare or threatened taxa amount to 19 , as $28.35 \%$ of the studied flora. These rare species are therefore of great value and have a high value in terms of conservation, either for heritage reasons or because of their risk of extinction (Pimm et al. 


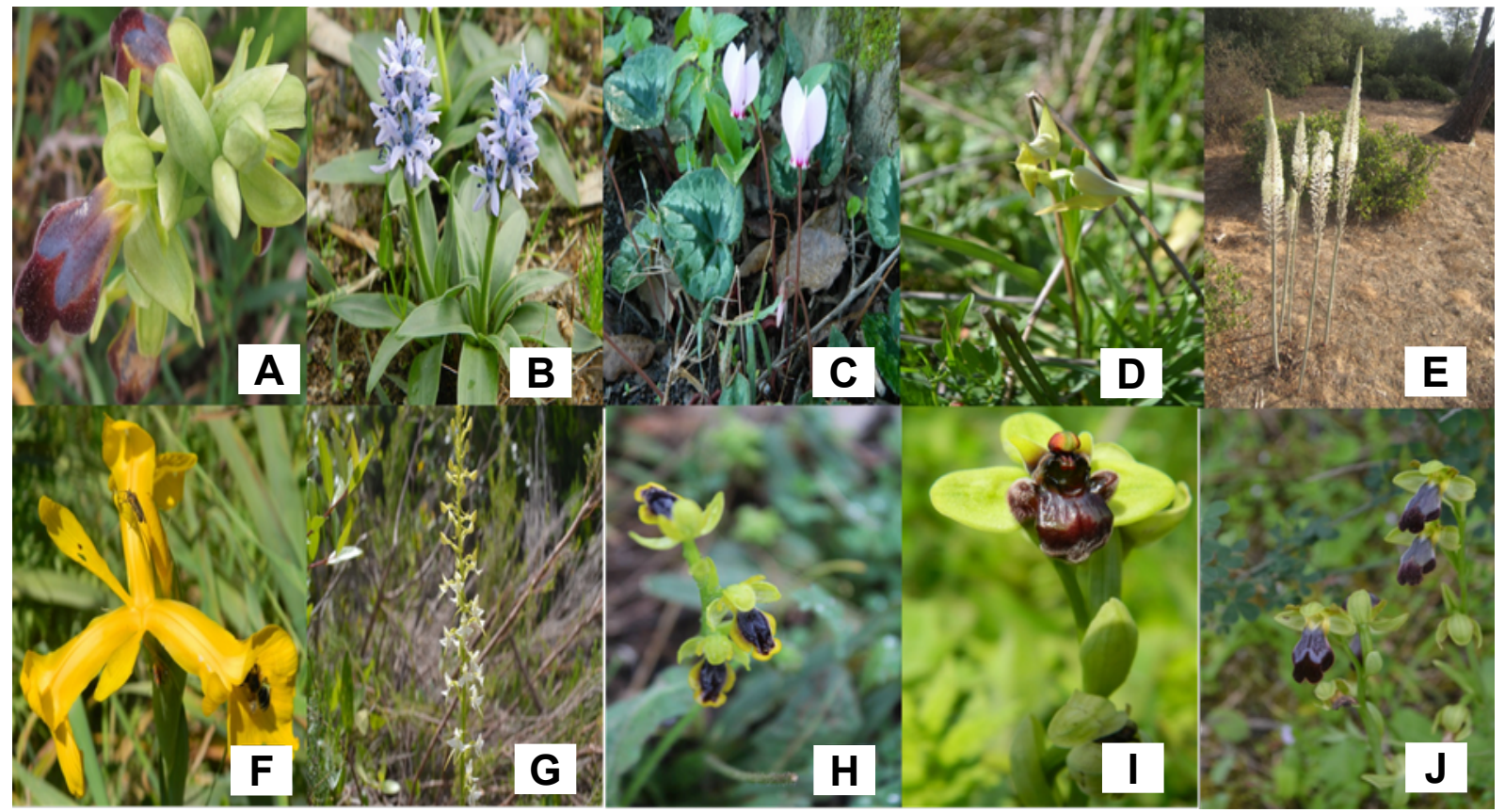

Figura/Figure 4. A: Ophrys fusca subsp: lupercalis; B: Hyacinthoides lingulata; C: Cyclamen africanum; D: Serapias stenopetala; E: Drimia numidica; F: Xiphion junceum; G: Platanthera bifolia; H: Ophrys numida; I: Ophrys bombyliflora; J: Ophrys iricolor.

1988, Gaston 1991, Hamel et al. 2013, Miara et al. 2017).

In fact, three recorded species are listed among the authoctonous and protected plant species, and three others are listed in the red list of IUCN (2017). This flora requires strict protection.

\section{Mosaic of the studied vegetation}

The plant mosaic of the studied area was found to be structured by three dominant environmental gradients; the rainfall, altitude and anthropogenic disturbances.

The habitat features are helpful to determine the plant distributions, and this is due to reason to their usually complex interactions with organisms (Gaston 1991). It seems that the precipitation abundance in the study area promoted the appearance of 38 bulbous species and 29 tuberous species, leading to population variation of every observed taxon.

The altitude determines the distribution of the observed species, since the low and the high altitudes are relatively poor in species, although average altitude stations were proved to be quite rich in floristic biodiversity. The presence of new populations of Allium commutatum in the maritime cliffs of Vielle Calle distanced $3 \mathrm{~km}$ from the first site «Medjez Ecchaï» (de Bélair et al. 2012), leads us to suggest that the other leek populations could be found in the western-coast, and even to the eastern of El-Kala city. The site of El-Ghora, distanced $820 \mathrm{~m}$, is the highest one among our sites, and thus it is indicated as the sole site of Hyacinthoides aristidis and Platanthera bifolia. The later has already been indicated in the same site by de Bélair et al. (2005). This AlgerianTunisian endemic taxon was observed in Edough peninsula found in high maquis at 594 MASL, in Pinus pinaster Aiton forests (Hamel et al. 2013, Kreutz et al. 2014, Hamel \& Meddad-Hamza 2016). Its presence on the Babor Mountain (North-Eastern of Algeria) with altitude of 1,935 MASL is being confirmed (Madoui et al. 2017).

\section{Threats and conservation}

As reported by Verlaque et al. (2001), the therophytes and the geophytes (bulbous and tuberous) are highly damaged either by the harvests or pastoral pressure. Indeed, the damages on the habitats are significantly high. These damages are frequently due to the humans and his expansion (flocks). According to Allem et al. (2017) these effects are direct, damaging habitats and species and they modified their groups of associated species.

The total elimination of pasturage in the longterm period, could lead to the removal of the environment and the development of competitive mono-specific communities (Belouahem et al. 2011), and this is not desirable. 


\begin{tabular}{|c|c|c|c|c|c|c|c|c|c|c|c|}
\hline Code & Station & Habitat & Coordinates & Altitude & Substratum & $\begin{array}{c}\text { Slope } \\
(\%)\end{array}$ & Exp & Trli (\%) & $\begin{array}{l}\text { Trhe } \\
(\%)\end{array}$ & $\begin{array}{l}\text { Surf. } \\
\left(\mathrm{m}^{2}\right)\end{array}$ & N spp \\
\hline R1 & Ain El Assel & Eucalyptaie & $\begin{array}{l}36^{\circ} 48^{\prime} 0.16^{\prime \prime} \mathrm{N} \\
8^{\circ} 23^{\prime} 0.73^{\prime \prime E}\end{array}$ & 30 & Numidian sandstone and clay & 4 & N & 18 & 35 & 35 & 9 \\
\hline R2 & $\begin{array}{l}\text { Bog of Lake } \\
\text { Noir }\end{array}$ & $\begin{array}{l}\text { Cork oak } \\
\text { forest }\end{array}$ & $\begin{array}{l}36^{\circ} 511^{\prime} 0.20^{\prime \prime} \mathrm{N} \\
8^{\circ} 12^{\prime} 0.33^{\prime \prime E}\end{array}$ & 36 & Sand & 7 & NW & 24 & 40 & 20 & 8 \\
\hline R3 & Ain El Kebir & $\begin{array}{l}\text { Cork oak } \\
\text { forest }\end{array}$ & $\begin{array}{l}36^{\circ} 38^{\prime} 0.86^{\prime \prime} \mathrm{N} \\
8^{\circ} 25^{\prime} 0.68^{\prime \prime} \mathrm{E}\end{array}$ & 580 & Numidian sandstone and clay & 17 & NW & 34 & 82 & 60 & 11 \\
\hline R4 & Ain Kechba & $\begin{array}{l}\text { Cork oak } \\
\text { forest }\end{array}$ & $\begin{array}{l}36^{\circ} 39^{\prime} 0.24^{\prime \prime} \mathrm{N} \\
8^{\circ} 24^{\prime} 0.18^{\prime \prime} \mathrm{E}\end{array}$ & 452 & Numidian sandstone and clay & 15 & NW & 27 & 80 & 55 & 10 \\
\hline R5 & Bougous & $\begin{array}{l}\text { Cork oak } \\
\text { forest }\end{array}$ & $\begin{array}{l}36^{\circ} 41^{\prime} 32.84 " \mathrm{~N} \\
8^{\circ} 23^{\prime} 6.19^{\prime \prime} \mathrm{E}\end{array}$ & 331 & Numidian sandstone and clay & 11 & $S$ & 30 & 39 & 80 & 11 \\
\hline R6 & El Fedjej & $\begin{array}{l}\text { Cork oak } \\
\text { forest }\end{array}$ & $\begin{array}{l}36^{\circ} 38^{\prime} 0.91^{\prime \prime} \mathrm{N} \\
8^{\circ} 22^{\prime} 0.97 " \mathrm{E}\end{array}$ & 382 & Numidian sandstone and clay & 13 & NW & 26 & 66 & 50 & 6 \\
\hline R7 & El Toual & Zenaie oak & $\begin{array}{l}36^{\circ} 39^{\prime} 0.16^{\prime \prime} \mathrm{N} \\
8^{\circ} 21^{\prime} 0.94^{\prime \prime E}\end{array}$ & 201 & Numidian sandstone and clay & 10 & NE & 22 & 51 & 50 & 7 \\
\hline R8 & Lhdeb & Lawn & $\begin{array}{l}36^{\circ} 38^{\prime} 0.82^{\prime \prime} \mathrm{N} \\
8^{\circ} 25^{\prime} 0.73^{\prime \prime E}\end{array}$ & 595 & Numidian sandstone and clay & 18 & NE & 20 & 47 & 82 & 12 \\
\hline R9 & $\begin{array}{l}\text { Biological plot } \\
\text { El Ghora }\end{array}$ & Zenaie oak & $\begin{array}{l}36^{\circ} 41^{\prime} 3.21^{\prime \prime N} \\
8^{\circ} 27^{\prime} 13.76^{\prime \prime} \mathrm{E}\end{array}$ & 445 & Numidian sandstone and clay & 22 & S & 40 & 81 & 100 & 4 \\
\hline R10 & Bourdim & Lawn & $\begin{array}{l}36^{\circ} 47^{\prime} 0.79^{\prime \prime} \mathrm{N} \\
8^{\circ} 14^{\prime} 0.85^{\prime \prime E}\end{array}$ & 19 & Numidian sandstone and clay & 3 & S & 10 & 72 & 36 & 5 \\
\hline R11 & El Aioun & Lawn & $\begin{array}{l}36^{\circ} 49^{\prime} 0.39^{\prime \prime} \mathrm{N} \\
8^{\circ} 36^{\prime} 0.18^{\prime \prime} \mathrm{E}\end{array}$ & 252 & Numidian sandstone and clay & 9 & SE & 5 & 40 & 49 & 7 \\
\hline R12 & Oued Djenan & Lawn & $\begin{array}{l}36^{\circ} 49^{\prime} 0.31 " \mathrm{~N} \\
8^{\circ} 37^{\prime} 0.46^{\prime \prime} \mathrm{E}\end{array}$ & 299 & Numidian sandstone and clay & 12 & SE & 4 & 90 & 200 & 28 \\
\hline R13 & Brabtia & $\begin{array}{l}\text { Cork oak } \\
\text { forest }\end{array}$ & $\begin{array}{l}36^{\circ} 511^{\prime} 0.74^{\prime \prime} \mathrm{N} \\
8^{\circ} 20^{\prime} 0.27^{\prime \prime E}\end{array}$ & 6 & Numidian sandstone and clay & 3 & NW & 40 & 81 & 90 & 17 \\
\hline R14 & $\begin{array}{l}\text { Chemin des } \\
\text { Oiseaux }\end{array}$ & $\begin{array}{l}\text { Cork oak } \\
\text { forest }\end{array}$ & $\begin{array}{l}36^{\circ} 52^{\prime} 0.33^{\prime \prime} \mathrm{N} \\
8^{\circ} 29^{\prime} 0.39^{\prime \prime} \mathrm{E}\end{array}$ & 47 & Numidian sandstone and clay & 6 & NE & 61 & 42 & 50 & 9 \\
\hline R15 & Djebel El Korsi & $\begin{array}{l}\text { Cork oak } \\
\text { forest }\end{array}$ & $\begin{array}{l}36^{\circ} 51^{\prime} 32.56 " \mathrm{~N} \\
8^{\circ} 15^{\prime} 57.62 " \mathrm{E}\end{array}$ & 125 & Numidian sandstone and clay & 4 & NW & 33 & 53 & 25 & 7 \\
\hline R16 & El Kala City & $\begin{array}{l}\text { Cork oak } \\
\text { forest }\end{array}$ & $\begin{array}{l}36^{\circ} 53^{\prime} 0.20^{\prime \prime} \mathrm{N} \\
8^{\circ} 26^{\prime} 0.09 " \mathrm{E}\end{array}$ & 86 & Numidian sandstone and clay & 3 & SE & 4 & 14 & 10 & 10 \\
\hline R17 & Feid El Allag & $\begin{array}{l}\text { Cork oak } \\
\text { forest }\end{array}$ & $\begin{array}{l}36^{\circ} 50^{\prime} 0.24^{\prime \prime} \mathrm{N} \\
8^{\circ} 28^{\prime} 0.07 " \mathrm{E}\end{array}$ & 5 & Numidian sandstone and clay & 7 & SE & 14 & 30 & 12 & 9 \\
\hline R18 & Mellah & Lawn & $\begin{array}{l}36^{\circ} 53^{\prime} 0.15^{\prime \prime} \mathrm{N} \\
8^{\circ} 20^{\prime} 0.55^{\prime \prime} \mathrm{E}\end{array}$ & 5 & Sand & 3 & NW & 10 & 77 & 20 & 13 \\
\hline R19 & Oubeira & $\begin{array}{l}\text { Cork oak } \\
\text { forest }\end{array}$ & $\begin{array}{l}36^{\circ} 51 \text { '0.99"N } \\
8^{\circ} 22^{\prime} 0.96 " \mathrm{E}\end{array}$ & 30 & Numidian sandstone and clay & 5 & SW & 32 & 52 & 40 & 10 \\
\hline $\mathbf{R} 20$ & $\begin{array}{l}\text { Point of } \\
\text { Chacal }\end{array}$ & $\begin{array}{l}\text { Marine } \\
\text { bangs }\end{array}$ & $\begin{array}{l}36^{\circ} 53^{\prime} 0.84^{\prime \prime} \mathrm{N} \\
8^{\circ} 26^{\prime} 0.05^{\prime \prime} \mathrm{E}\end{array}$ & 1 & $\begin{array}{l}\text { Numidian sandstone and } \\
\text { mixed series }\end{array}$ & 1 & N & 1 & 20 & 5 & 2 \\
\hline R21 & Souk Reguibat & $\begin{array}{l}\text { Cork oak } \\
\text { forest }\end{array}$ & $\begin{array}{l}36^{\circ} 53^{\prime} 0.97^{\prime \prime} \mathrm{N} \\
8^{\circ} 17^{\prime} 0.33^{\prime \prime E}\end{array}$ & 15 & Sand & 3 & NE & 9 & 31 & 14 & 6 \\
\hline R22 & Tonga & Lawn & $\begin{array}{l}36^{\circ} 52^{\prime} 0.77^{\prime \prime} \mathrm{N} \\
8^{\circ} 30^{\prime} 0.81 " \mathrm{E}\end{array}$ & 9 & Numidian sandstone and clay & 6 & NE & 11 & 75 & 50 & 8 \\
\hline R23 & Vieille Calle & Maritime cliff & $\begin{array}{l}36^{\circ} 55^{\prime} 8.27^{\prime \prime N} \\
8^{\circ} 19^{\prime} 38.47^{\prime \prime} \mathrm{E}\end{array}$ & 9 & $\begin{array}{l}\text { Numidian sandstone and } \\
\text { mixed series }\end{array}$ & 11 & $\mathrm{~N}$ & 20 & 40 & 10 & 10 \\
\hline R24 & Ain Khiar & $\begin{array}{l}\text { Cork oak } \\
\text { forest }\end{array}$ & $\begin{array}{l}36^{\circ} 48^{\prime} 0.26^{\prime \prime} \mathrm{N} \\
8^{\circ} 19^{\prime} 0.27 " \mathrm{E}\end{array}$ & 36 & Numidian sandstone and clay & 4 & NE & 38 & 53 & 10 & 9 \\
\hline R25 & Ain Smail & $\begin{array}{l}\text { Cork oak } \\
\text { forest }\end{array}$ & $\begin{array}{l}36^{\circ} 47^{\prime} 0.76 " \mathrm{~N} \\
8^{\circ} 35^{\prime} 0.20^{\prime \prime E}\end{array}$ & 289 & Numidian sandstone and clay & 15 & NE & 19 & 28 & 6 & 6 \\
\hline R26 & Oued El Hout & $\begin{array}{l}\text { Cork oak } \\
\text { forest }\end{array}$ & $\begin{array}{l}36^{\circ} 49^{\prime} 0.377^{\prime \prime N} \\
8^{\circ} 30^{\prime} 0.04 " \mathrm{E}\end{array}$ & 9 & Numidian sandstone and clay & 3 & NE & 11 & 33 & 60 & 9 \\
\hline R27 & R'mel Souk & Eucalyptaie & $\begin{array}{l}36^{\circ} 47^{\prime} 0.66 " \mathrm{~N} \\
8^{\circ} 30^{\prime} 0.10^{\prime \prime} \mathrm{E}\end{array}$ & 90 & Numidian sandstone and clay & 4 & SE & 16 & 29 & 45 & 11 \\
\hline R28 & Hadada & $\begin{array}{l}\text { Cork oak } \\
\text { forest }\end{array}$ & $\begin{array}{l}36^{\circ} 53^{\prime} 0.63^{\prime \prime N} \\
8^{\circ} 37^{\prime} 0.15^{\prime \prime} \mathrm{E}\end{array}$ & 179 & Numidian sandstone and clay & 22 & NE & 39 & 86 & 100 & 15 \\
\hline R29 & Segleb & $\begin{array}{l}\text { Cork oak } \\
\text { forest }\end{array}$ & $\begin{array}{l}36^{\circ} 56^{\prime} 15.64 " \mathrm{~N} \\
8^{\circ} 36^{\prime} 18.75 " \mathrm{E}\end{array}$ & 9 & Numidian sandstone and clay & 25 & $\mathrm{NE}$ & 70 & 51 & 15 & 4 \\
\hline R30 & Souarekh & $\begin{array}{l}\text { Cork oak } \\
\text { forest }\end{array}$ & $\begin{array}{l}36^{\circ} 52^{\prime} 0.29^{\prime \prime} \mathrm{N} \\
8^{\circ} 36^{\prime} 0.14^{\prime \prime} \mathrm{C}\end{array}$ & 118 & Numidian sandstone and clay & 11 & NE & 19 & 30 & 36 & 7 \\
\hline
\end{tabular}

Tabla 4. Ubicación geográfica de los sitios muestreados a nivel; Tasa de cobertura arbórea (Trli); Tasa de recuperación de la hierba (Trhe); Superficie ocupada por las bulbosas $\left(\mathrm{m}^{2}\right)$; Exp: Exposición; Surf: Superficie; Nsps: Número de especies colectadas.

Table 4. Geographical location of sites sampled at the PNEK level. Tree cover rate (Trli); Herb recovery rate (Trhe); Bulb surface area $\left(\mathrm{m}^{2}\right)$; Exp: Exhibition; Pent: Slope; Surf: Surface; N sp s: Number of species surveyed. 
Therefore, an integrated strategy for the conservation of threatened taxa or showing heritage interest must absolutely be based on a good knowledge of the auto-ecology and biology of rare species (Quézel \& Médail 2003).

\section{Conclusions}

The results obtained reveal a high species richness (67 species), characterized by a relatively high rate of endemism $(28.35 \%)$, a large number of rare, endangered and endemic species (19 species, 10 of which are rare to very rare) and a great biogeographical diversity, marked by the coexistence of elements of Mediterranean, Nordic, endemic and introduced origin.

This inventory allowed us to discover and refer new stations of geophytes by indicating a new species for the region in question (Ophrys fusca subsp. lupercalis).

In terms of conservation, it is necessary to recall the need to rapidly implement measures to protect the stations of the species observed in the study area, by announcing the degraded state of the bulbous habitats and to be concerned about threats to these plants, because indeed human activity modifies and restricts the environments in which the geophyte species develop spontaneously and thus jeopardizes the diversity of these taxa, for that a control of overgrazing and fires is necessary.

Finally, an important step must be taken in the protection of species. The lists of protected species need to be revised to include newly described taxa that are already in danger and those that are newly threatened.

\section{Acknowledgements}

The authors gratefully thank M. Boucheker Abdennour for the valuable assistance.

\section{References}

Allem M, Hamel T, Tahraoui C, Boulemtafes A \& Bouslama Z. 2017. Diversité floristique des mares temporaires de la région d'Annaba (Nord-Est algérien). International Journal of Environmental Studies 75 (3): 405-424.

Barbéro M, Loisel R, Médail F \& Quézel P. 2001. Signification biogéographique et biodiversité des forêts du bassin méditerranéen. Bocconea 13: 1125.
Barthlott W, Biedinger N, Braun G, Feig F, Kier G \& Mutke J. 1999. Terminological and methodological aspects of the mapping and analysis of global biodiversity. Acta Botanica Fennica 162: 103-110.

Beghami Y, Véla E, de Bélair G \& Thinon M. 2015. Contribution on the knowledge of the orchids of the Aures (N.E. of Algeria): inventory, cartography, taxonomy and ecology. Revu d'Ecologie (La Terre et La Vie) 70: 354-370.

Belouahem-Abed D, Belouahem F, Benslama $M$, de Bélair G \& Muller SD. 2011. Les aulnaies de Numidie (N.E. algérien): biodiversité floristique, vulnérabilité et conservation. Comptes Rendus Biologies 334: 61-73.

Bennadja S, de Bélair G \& Ait Kaki Y. 2013. La subéraie de la Numidie orientale: une source de biodiversité. Quaderni di Botanica ambientale e applicata 24: 4953.

Benyacoub S \& Chabi Y. 2000. Diagnose Ecologique de l'avifaune du Parc National d'El Kala. Synthèse 7: 34-46.

Blanca G, Cabezudo B, Cueto M, Lopez CF \& Torres CM. 2009. Flora Vasculair de Andalucía Oriental. 4 Tomes. Consejería de Medio Ambiente. Junta de Andalucía.

Boubetra K, Amirouche N \& Amirouche R. 2017. Comparative morphological and cytogenetic study of five Asparagus (Asparagaceae) species from Algeria including the endemic $A$. altissimus Munby. Turkish Journal of Botany 41: 588-599.

Bougaham AF, Bouchibane M \& Véla E. 2015. Inventaire des orchidées de la Kabylie des Babors (Algérie), éléments de cartographie et enjeux patrimoniaux. Journal Europäischer Orchideen 47: 88-110.

Boukehili K, Boutabia L, Telailia S, Menaa M, Tlidjane A, Maazi MC, Chefrour A, Saheb M \& Véla E. 2018. Les Orchidées De La Wilaya De Souk Ahras (NordEst algérien): Inventaire, écologie, répartition et enjeux. Revue d'écologie (Terre et Vie) 73(2): 167179.

Boulos L. 1997. Endemic flora of the Middle East and North Africa. p. 229-260 in: Barakat HN, Hegazy AK (ed), Review in Ecology: Desert Conservation and Development. Cairo: Metropole.

Brahmia Z, Dziri H, Benyacoub S \& Chabi Y. 2002. Biology of shrike (Lanus senator) in North East of Algeria. Revue d'écologie (Terre et Vie) 62: 128-134.

Core Team R. 2013. R: A language and environment for statistical computing. R Foundation for statistical computing, Vienna, Austria. http://www.R-project.org

Daget PH \& Gaston A. 2001. La base FLOTROP et biodiversité des pâturages du Tchad oriental. Systematics and Geography of Plants 71 (2): 327333.

Danin A \& Orshan G. 1990. The distribution of Raunkiaer life forms in Israel, in relation to the environment. Journal of vegetation science 1: 41-48.

Dray S, Dufour AB \& Thioulouse J. 2018. ade4: Analysis of Ecological Data: Exploratory and Euclidean Methods in Environmental Sciences. $\mathrm{R}$ package. Available at [https://cran.r-project.org/web/packages/ ade4/index.html] (accessed on 10-XI-2018). 
de Bélair G. 1990. Structure, fonctionnement et perspectives de gestion de quatre éco-complexes lacustres et marécageux: El Kala, Est algérien: university of Annaba. Doctoral Thesis.

de Bélair G. 2000. Les orchidées de la Numidie. 1ère partie: taxonomie et iconographie. L'orchidophile 144: 220-230.

de Bélair G. 2005. Dynamique de la végétation de mares temporaires en Afrique du Nord (Numidie orientale, NE Algérie). Ecologia Mediterranea 31: 83-100.

de Belair G, Belouahem F, Belouahem-Abed D \& Véla E. 2012. Première signalisation d'Allium commutatum Guss. (Alliaceae) sur le continent africain (Algérie). Lagascalia 32: 312-314.

de Bélair G, Véla E \& Boussouak R. 2005. Inventaire des orchidées de Numidie (N.E Algérie) sur vingt années. Journal Europäischer Orchideen 37: 291401.

Devillers P \& Devillers-Terschuren J. 1994. Essai d'analyse systématique du genre Ophrys. Naturalistes belges 75 (7): 273-400.

Dobignard A \& Chatelain C. 2010-2013. Index synonymique de la flore d'Afrique du Nord. Eds des Conservatoire et jardin botanique de Genève, (C.J.B.G). Available online at: http://www.villege.ch/musinfo/bd/cjb/africa/.

Emberger L. 1955. Une classification biogéographique des climats. Recueil des Travaux des Laboratoires de Botanique, Géologie et Zoologie de la Faculté des Sciences de L'Université de Montpellier, Série Botanique 7: 1-43.

Gaston KJ. 1991. How large is species geographical range?. Oikos 61: 434-438.

Hamel T. 2013. Contribution à l'étude de l'endémisme chez les végétaux vasculaires dans la péninsule de l'Edough (Nord-Est algérien). Annaba, Algeria: University of Annaba. Doctoral Thesis.

Hamel T \& Boulemtafes A. 2017. Découverte d'une endémique tyrrhénienne Soleirolia soleirolii (Urticaceae) en Algérie (Afrique du Nord). Flora Mediterranea 27: 185-193.

Hamel T \& Meddad-Hamza A. 2016. Note sur les orchidées de la péninsule de l'Edough (Nord-Est algérien). L'Orchidophile 211(4): 79-86.

Hamel T, Meddad-Hamza A \& Mabarek-Oudina A. 2017. De nouvelles perspectives pour les orchidées de la région de Skikda (Nord-Est algérien). Journal Europäischer Orchideen 49 (1): 61-78.

Hamel T, Seridi R, de Bélair G, Slimani AR \& Babali B. 2013. Flore vasculaire rare et endémique de la péninsule de l'Edough (Nord-Est algérien). Revue Synthèse des Sciences et de la Technologie 26: 6574.

Décret exécutif du 18 janvier 2012, complétant la liste des espèces végétales non cultivées et protégées. Journal Officiel de la République Algérienne 3, 1801-2012, pp. 12-38. Argelia. https://www.joradp.dz/ FTP/JO-FRANCAIS/2012/F2012003.pdf\#page $=12$

Joleaud L. 1936. Étude géologique de la région de Bône et de La Calle. Bulletin du Service de la Carte Géologique de L'Algérie. $2^{\mathrm{e}}$ Série StratigraphieDescriptions régionales 12. Alger: Gouverment
Général de L’Algerie.

Kreutz CAJ, Rebbas K, de Belair G, Miara MD \& Ait Hammou M. 2014. Erganzungen, Korrekturen und neue Erkentnisse zu den Orchideen Algeriens. Ber Arbeitskrs Heim Orchid 31 (2): 140-206.

Kreutz CAJ, Rebbas K, Miara MD, Babali B \& AitHammou M. 2013. Neue Erkentnisse zu den Orchideen Algeriens. Ber Arbeitskrs Heim Orchid 30 (2): 185-270

Le Floc'h E, Boulos L \& Véla E. 2010. Catalogue synonymique commenté de la flore de Tunisie. Tunis: Banque nationale de gènes de la Tunisie.

Legendre P \& Legendre L. 2012. Numerical ecology. Amsterdam: Elsevier Science.

Madoui M, Rebbas K, Bounar R, Miara MD \& Véla E. 2017. Contribution à l'inventaire des Orchidées de la wilaya de Sétif (nord-est de l'Algérie). Bulletin mensuel de la Société linnéenne de Lyon 86 (9-10): 273-292.

Maire R. 1952-1987. Flore de l'Afrique du Nord (Maroc, Algérie, Tunisie, Tripolitaine, Cyrénaïque et Sahara). Paris: Le Chevalier.

Marre A. 1987. Etude géomorphologique du Tell Oriental Algérien de Collo à la frontière tunisienne: Universty of Aix-Marseille. Doctoral Thesis.

Marre M. 1992. Le tell Orientale algérien de Collo à la frontière tunisienne. Etude géomorphologique. Alger: OPU.

Martin R, Véla E \& Ouni R. 2015. Orchidées de Tunisie. Bulletins Archives Société Botanique du Centre Ouest 44: 1-160.

Médail F \& Diadema K. 2006. Biodiversité végétale méditerranéenne et anthropisation: approches macro- et micro-régionales. Annales de Géographie 651: 618-640.

Médail F \& Quézel P. 1999, Biodiversity hotspots in the Mediterranean Basin: setting global conservation priorities. Conservation Biology 13: 1510-1513.

Médail F \& Quézel P. 1997. Hot-spot analysis for conservation of plants biodiversity in the Mediterranean Basin. Annals of the Missouri Botanical Garden 84: 112-127.

Miara MD, Ait Hammou M, Rebbas K \& Bendif H. 2017. Flore endémique, rare et menacée de l'Atlas tellien occidental de Tiaret (Algérie). Acta Botanica Malacitana 42(2): 271-285.

Myers N, Mittermeier RA, Mittermeier CG, Da Fonseca GAB \& Kent J. 2000. Biodiversity hotspots for conservation priorities. Nature 403: 853-858.

Parsons RF \& Hopper SD. 2003. Monocots geophytes: a comparison of South-Western Australia with other areas of Mediterranean climate. Australian Journal of Botany 51:129-133.

Pignatti S. 1982. Flora d'Italia. Bologna: Edagricole.

Pimm SL, Jones HL \& Diamond J. 1988. On the risk of extinction. The American Naturalist 132: 757-785.

Procheş S, Cowling RM, Goldblatt P, Manning JC \& Snijman DA. 2015. An overview of the Cape geophytes. Biological Journal of the Linnean Society 87:27-43

Quézel P \& Médail F. 2003. Écologie et biogéographie des forêts du bassin méditerranéen. Paris: Elsevier. 
Quézel P \&Santa S. 1962-1963. Nouvelle flore de l'Algérie et des régions désertiques méridionales. Paris: CNRS.

Quézel P. 1964. L'endémisme dans la flore d'Algérie. Comptes Rendus de la Société de biogéographie 361: 137-149.

Quézel P. 1978. Analysis of the flora of Mediterranean and Saharan Africa. Annals of the Missouri Botanical Garden 65: 479-537.

Quézel P. 1983. Flore et végétation de l'Afrique du Nord, leur signification en fonction de l'origine, de l'évolution et des migrations des flores et structures de végétation passées. Bothalia 14: 411-416.

Quézel P. 2000. Réflexions sur l'évolution de la flore et de la végétation au Maghreb méditerranéen. Paris: Ibis Press.

Rebbas K \& Véla E. 2013. Observations nouvelles sur les Pseudophrys du Centre-Est de l'Algérie septentrionale. Journal Europäischer Orchideen 45: 501-517.

Rebbas K \& Véla E. 2008. Découverte d'Ophrys mirabilis P. Geniez \& F. Melki en Kabylie (Algérie). Le monde des plantes 496: 13-16.

Rouag R, Berrahma I \& Luiselli L. 2006. Food habits and daily activity patterns of the North African ocellated lizard Timon pater from North Eastern Algeria. Journal of Natural History 40(21-22): 13691379.

Seltzer P. 1946. Le climat de l'Algérie. Argel: "La TypoLitho" et Jules Carbonel.

Stevenson A, Skinner J, Hollis G \& Smart M. 1988. The El Kala Park and environs, Algeria: An ecological evaluation. Environmental Conservation 15 (4): 335348.

Ter Braak CJF. 1995. Ordination: Data analysis in community and landscape ecology. in: Jongman
RHG, Ter Braak CJF, Van Tongeren OFR. (eds). Ordination: Data analysis in community and landscape ecology. Cambridge University Press, Cambridge.

Tison JM \& de Foucault B. 2014. Flora Gallica: flore de France. Mèze: Biotope.

UICN. 2017. Liste rouge de I'UICN des espèces menacées. Version 2017-3. http://www.iucnredlist. org

Véla E \& Benhouhou S. 2007. Evaluation d'un nouveau point chaud de biodiversité végétale dans le bassin méditerranéen (Afrique du Nord). Comptes Rendus Biologies 330: 589-605.

Véla E, de Bélair G, Rosato M \& Rosselló J. 2016. Taxonomic remarks on Scilla anthericoides Poir. (Asparagaceae, Scilloideae), a neglected species from Algeria. Phytotaxa 288 (2): 154-160.

Verlaque R, Médail F \& Aboucaya A. 2001. Valeur prédictive des types biologiques pour la conservation de la flore méditerranéenne. Life Sciences 324: 1157-1165.

Verlaque R, Médail F, Quézel P \& Babinot JF. 1997. Endémisme végétal et paléogéographie dans le Bassin méditerranéen. Geobios 21: 159-166.

Veselý P, Bureš P, Šmarda P \& Pavlíček T. 2012. Genome size and DNA base composition of geophytes: the mirror of phenology and ecology?. Annals of Botany 109: 65-75.

Yahi N \& Benhouhou S. 2010. Zones importantes pour les plantes en Méditerranée méridionale et orientale. Sites prioritaires pour la conservation. UICN, p. 2730.

Yahi N, Véla E, Benhouhou S, de Bélair G \& Gharzouli R. 2012. Identifying Important Plants Areas (Key Biodiversity Areas for Plants) in Northern Algeria. Journal of Threatened Taxa 4: 2453-2765. 